\title{
Osmotic stress induces genes, enzymes and accumulation of galactinol, raffinose and stachyose in seedlings of pea (Pisum sativum L.)
}

\author{
Wioletta E. Pluskota ${ }^{1}$ Joanna Szablińska ${ }^{1} \cdot$ Ralph L. Obendorf $^{2} \cdot$ \\ Ryszard J. Górecki ${ }^{1} \cdot$ Lesław B. Lahuta $^{1}$
}

Received: 28 January 2015/Revised: 22 April 2015/ Accepted: 6 July 2015/Published online: 29 July 2015

(c) The Author(s) 2015. This article is published with open access at Springerlink.com

\begin{abstract}
The objective of the present study was to recognize the molecular background of the accumulation of raffinose family oligosaccharides (RFOs) in pea (Pisum sativum L.) seedlings under osmotic stress conditions. The exposure of 5-day-old pea seedlings to osmotic stress for $48 \mathrm{~h}$ created by immersing roots in PEG8000 solution $(-1.5 \mathrm{MPa})$ induced synthesis of galactinol and RFOs (raffinose and stachyose) in the epicotyl and root tissues, but not in cotyledons. After $24 \mathrm{~h}$ of recovery, galactinol completely disappeared, raffinose decreased fourfold and stachyose decreased twofold in roots, but increased in epicotyls. The temporary accumulation of RFOs resulted from a dramatic increase in the enzymatic activity and changes in expression of galactinol synthase (PsGolS), raffinose synthase $(P S R S)$ and stachyose synthase (PSSTS) genes. PsGolS was induced by osmotic stress in both epicotyls as well as in roots. PsRS and PSSTS were induced only in epicotyls, but repressed or remained unaffected in roots, respectively. During recovery, the expression and activity of PsGolS, PsRS and PsSTS dramatically decreased. The expression of PsGolS gene, that level of mRNA transcript significantly decreased during recovery
\end{abstract}

Communicated by J. Zwiazek.

Electronic supplementary material The online version of this article (doi:10.1007/s11738-015-1905-9) contains supplementary material, which is available to authorized users.

Lesław B. Lahuta

lahuta@uwm.edu.pl

1 Department of Plant Physiology, Genetics and Biotechnology, University of Warmia and Mazury in Olsztyn, ul. Oczapowskiego 1A/103, 10-718 Olsztyn, Poland

2 Professor Emeritus, Seed Biology, School of Integrative Plant Science, Cornell University, Ithaca, NY 14853-1901, USA and whose promoter region was identified to contain some stress-related regulating elements, seems to play a crucial role in the biosynthesis of RFOs under osmotic stress. Possible signals that may trigger the induction of expression of PsGolS, PsRS and PsSTS genes and accumulation of RFOs in pea seedlings are discussed.

Keywords Pea $\cdot$ Seedling - Osmotic stress - Galactinol synthase $\cdot$ Raffinose synthase $\cdot$ Stachyose synthase

Abbreviations
$\begin{array}{ll}\text { RFOs } & \text { Raffinose family oligosaccharides } \\ \text { GolS } & \text { Galactinol synthase (EC 2.4.1.123) } \\ \text { PEG8000 } & \text { Polyethylene glycol } 8000 \\ \text { ROS } & \text { Reactive oxygen species } \\ \text { RS } & \text { Raffinose synthase (EC 2.4.1.82) } \\ \text { STS } & \text { Stachyose synthase (EC 2.4.1.67) }\end{array}$

\section{Introduction}

Plant yields can be substantially reduced by adverse environmental events, for example drought, salinity and low and high temperatures. The ability of plants to survive environmental stresses arises from the evolution of various protective mechanisms, including stress-responsive gene expression, modulation of gene expression by the plant hormone abscisic acid (Qin et al. 2011), synthesis of stressassociated proteins (Komatsu and Hossain 2013) and the accumulation of certain osmoprotectants or compatible solutes (Yancey 2005). Osmoprotectants, which are neutral and non-toxic, small, organic metabolites, help to maintain water homeostasis in cells during an early response to 
stress conditions. Among organic osmolytes, the most widespread in plants are some soluble carbohydrates, such as sucrose, galactinol, raffinose family oligosaccharides (RFOs), polyols (myo-inositol, sorbitol, mannitol), inositol derivatives ( $O$-methyl-inositols, such as D-pinitol, D-ononitol), amino acids (glycine, proline), methylamines (glycine betaine) and methylsulfonium solutes (Yancey 2005). The accumulation of organic osmolytes in response to osmotic stress enables osmotic adjustment of cells and maintains their turgor. The presence of some organic osmolytes indicates the plant's ability to protect macromolecules from destabilization; they are engaged in unique reactions (antioxidant, cellular redox balance, detoxification of sulfide) protecting cellular metabolism (Yancey 2005). Recently, the concept of a dual role of RFOs (represented by raffinose, stachyose and verbascose), acting as osmoprotecting and compatible solutes, has been advocated (ElSayed et al. 2014). The biosynthesis of RFOs includes successive transfer of galactose moiety from galactinol $(\alpha$-D-galactopyranosyl-(1 $\rightarrow 1)-1$ L-myo-inositol) to sucrose, raffinose ( $\alpha$-D-galactopyranosyl- $(1 \rightarrow 6)$ - $\alpha$-D-glucopyranosyl$(1 \rightarrow 2)-\beta$-D-fructofuranoside) and stachyose $(\alpha$-D-galactopyranosyl-( $1 \rightarrow 6)$ - $\alpha$-D-galactopyranosyl- $(1 \rightarrow 6)-\alpha$-Dglucopyranosyl-(1 $\rightarrow$ 2)- $\beta$-D-fructofuranoside), producing an appropriate $\alpha$-D-galactoside, i.e., raffinose, stachyose and verbascose ( $\alpha$-D-galactopyranosyl- $(1 \rightarrow 6)$ - $\alpha$-D-galactopyranosyl-( $1 \rightarrow 6)$ - $\alpha$-D-galactopyranosyl- $(1 \rightarrow 6)-\alpha$-Dglucopyranosyl-(1 $\rightarrow$ 2)- $\beta$-D-fructofuranoside) (Peterbauer and Richter 2001). In each step of the RFOs biosynthesis, myo-inositol is released from galactinol. myo-Inositol and its derivatives (phosphatidylinositols, myo-inositol polyphosphates, galactinol) have diverse functions in plants-for example, they participate in stress responses (Valluru and Van den Ende 2011). Sucrose, myo-inositol and RFOs are ubiquitous storage soluble carbohydrates in seeds of many plant species (Obendorf and Górecki 2012). The biosynthesis of RFOs in developing seeds begins during the middle stage of embryo growth and becomes more intensive during seed maturation (Obendorf 1997). The accumulation of higher amounts of RFOs in the late maturation stages coincides with the acquisition of desiccation tolerance by the embryo, and RFO accumulation continues during natural tissue dehydration. In pea (Pisum sativum L.), Vicia sp. and soybean (Glycine max (L.) Merr.), $70 \%$ of RFOs may accumulate after occurrence of maximum seed dry weight (Górecki et al. 2000; Lahuta et al. 2005; Obendorf et al. 2009). Artificial drying of immature embryos or exposure of plants to drought, accelerating seed maturation, both lead to a higher RFO content (Obendorf and Górecki 2012). In seeds, RFOs can stabilize membranes during dehydration and extend the longevity of seeds. Raffinose protects sucrose by preventing crystallization during the withdrawal of water, and the vitrified cytoplasm is stabilized when a sufficient amount of raffinose is present (Sun and Leopold 1997).

In vegetative tissues and storage organs other than seeds (tubers, shoots), RFOs can be stored in vacuoles of cells and/or are transported through the phloem from source to sink tissues. The protective role of RFOs in vegetative tissues is less thoroughly explained. The accumulation of galactinol and raffinose in vegetative tissues of different plant species occurs under cold, heat, drought and osmotic stresses (ElSayed et al. 2014; Pastorczyk et al. 2014). The concentrations of accumulated galactinol and/or raffinose can be sufficiently high to confirm the osmoprotective role of both galactosides (Sun et al. 2013; Wang et al. 2012a; $\mathrm{Wu}$ et al. 2009). However, in dehydrated seedlings of wheat (Bogdan and Zagdańska 2006), winter vetch (Vicia villosa Roth) (Lahuta and Górecki 2011) and pea (Lahuta et al. 2014), the concentration of accumulated raffinose is very low. On the other hand, it is suspected that RFOs can be involved in plants' cold or heat tolerance (Guy et al. 2008). Interestingly, the antioxidant activity of galactinol and raffinose has been discovered in some research (Nishizawa et al. 2008). The participation of RFOs and fructans (fructosyl sucrose oligosaccharides) in response to oxidative stress was postulated by Van den Ende and Valluru (2009). Fructans and RFOs may contribute to an overall cellular homeostasis of reactive oxygen species (ROS) by specific ROS scavenging processes in the vicinity of organelle membranes (e.g., vacuole, chloroplasts) (Keunen et al. 2013). However, most data indicating the participation of RFOs in plant stress response are derived from experiments conducted on mature photosynthetically active leaves and/or developing embryos (ElSayed et al. 2014; Obendorf and Górecki 2012). Our previous study (Lahuta and Górecki 2011; Lahuta et al. 2014) showed that seedlings can be a good object for studying the role of RFOs in tissue response to osmotic stress. We have found that osmotic stress induces the activity of galactinol synthase (GolS, EC 2.4.1.123) and raffinose synthase (RS, EC 2.4.1.82) in both epicotyl and root tissues of 7-day-old seedlings of winter vetch, but not in cotyledons (Lahuta and Górecki 2011). Similarly, dehydration induces expression and activity of GolS and RS in both epicotyl and root tissues of 7-day-old seedlings of pea (Lahuta et al. 2014). Although seedlings accumulated galactinol and raffinose, the concentrations of both galactosides was several-fold lower than that of sucrose. Nevertheless, the disappearance of galactinol and raffinose after stress recovery seems to be a direct confirmation of the participation of both sugars in tissue response to osmotic stress (Lahuta and Górecki 2011). The molecular background of the synthesis of RFOs under osmotic stress has been explained only partially (Lahuta et al. 2014; Maia et al. 2014). We have discovered that in the response of 
7-day-old pea seedling to fast desiccation, the synthesis of galactinol and raffinose correlated with an early induction (during the first hour of treatment) of galactinol synthase $(P s G o l S)$ and raffinose synthase (PsRS) gene expression and subsequent increase in enzymatic activity of both enzymes (Lahuta et al. 2014). In the present study, we compared the accumulation of RFOs in pea seedlings with changes in expression of PsGolS and PsRS genes and the activity of GolS and RS enzymes during $48 \mathrm{~h}$ of osmotic stress (in PEG solution, at $-1.5 \mathrm{MPa}$ ) and after $24 \mathrm{~h}$ of recovery. For the first time, the expression of stachyose synthase gene (PSSTS, Pisum sativum stachyose synthase) and activity of stachyose synthase enzyme (STS, EC 2.4.1.67) in osmotic-stressed pea seedlings were analyzed. Moreover, the promoter regions of PsGolS as well as PsRS genes were identified and their role in triggering of RFOs biosynthetic pathway in stress response was discussed.

\section{Materials and methods}

\section{Plant material}

Seeds of pea (Pisum sativum L., cv. Hubal) obtained from Danko (Poland) were surface sterilized in ethanol:water $(60: 40, v / v)$ for $1 \mathrm{~min}$, rinsed three times with sterile double distilled water and germinated on wet germination paper towels (Eurochem BGD, Poland) at $20{ }^{\circ} \mathrm{C}$ in the dark for 7 days. The changes in the content and composition of soluble carbohydrates were monitored separately in the epicotyl, root (including small amount of hypocotyl) and cotyledons, at 24-h intervals during the 7 days of seed germination. Five-day-old seedlings, in which raffinose family oligosaccharides were completely degraded in tissues of both the epicotyl and root (and only traces of RFOs remained in cotyledons), were used in the osmotic stress experiment.

\section{Osmotic stress}

After 5 days of germination, seedlings (in each of the 9 replicates) were transferred into glass tubes $(10 \mathrm{~cm}$ length, $15 \mathrm{~mm}$ diameter, ten seedlings per tube) containing $20 \mathrm{~mL}$ of water (control) or polyethylene glycol solutions (PEG8000, Sigma) of the osmotic potential $-1.5 \mathrm{MPa}$, obtained by dissolving appropriate amounts of PEG8000 in water (Michel 1983). This osmotic potential was chosen based on the results of preliminary studies. Treatment of 5-day-old pea seedlings with osmotic stress at different osmotic potentials $(-0.5,-1.0,-1.5$ and $-2.0 \mathrm{MPa})$ for $48 \mathrm{~h}$ resulted in an accumulation of RFOs in epicotyls and roots, but not in cotyledons (unpublished data). However, seedlings incubated at $-2.0 \mathrm{MPa}$ for $48 \mathrm{~h}$ were not able to resume growth after replacement of PEG8000 solution with water. In the present study, only the roots were immersed in the PEG solution $(-1.5 \mathrm{MPa})$ and seedlings were incubated in a climatic chamber (in the dark at $22{ }^{\circ} \mathrm{C}$ ) for $48 \mathrm{~h}$. Samples of epicotyls, roots and cotyledons were collected before stress, after 24 and $48 \mathrm{~h}$ of osmotic stress and after replacement of the PEG solution with water (for $24 \mathrm{~h}$ ). Tissues were weighed, frozen in liquid nitrogen and stored at $-72{ }^{\circ} \mathrm{C}$. Samples for soluble carbohydrate analysis (all parts of seedlings) and enzymatic activity determination (epicotyls and roots) were lyophilized in a freeze dryer (Alpha 1-2LD, Christ, Germany) and stored at $-20{ }^{\circ} \mathrm{C}$ prior to analyses. The experiment was repeated three times.

\section{Analysis of soluble carbohydrates}

Dry, lyophilized tissues were pulverized to a fine powder in a mixer mill (MM 200, Retsch, Verder Group, Netherlands) before extraction of soluble carbohydrates. The method of extraction has been previously described in detail (Lahuta and Górecki 2011). Briefly, carbohydrates were extracted from the dry flour with $50 \%$ ethanol at $90{ }^{\circ} \mathrm{C}$. After centrifugation, the homogenate was deionized (by mixing with ion exchangers) and dried in a speed vacuum rotary evaporator to dryness (Peterbauer et al. 2001). Dry residues containing soluble carbohydrates were derivatized with a mixture of trimethylsilylimidazole (TMSI) and pyridine (1:1, v/v). TMS-derivatives of carbohydrates were analyzed by the high-resolution gas chromatography method on a gas chromatograph GC2010 (Shimadzu, Japan) with a capillary column ZEBRON ZB-1 (Phenomenex, USA). Carbohydrates were quantified by using standards: myo-inositol, sucrose, raffinose, stachyose (purchased from Sigma), verbascose (Megazyme International, Ireland) and galactinol (Wako Pure Chemicals Industries Ltd., Japan). The content of carbohydrates was calculated from the standard curves of appropriate components. Xylitol (Fluka) was used as an internal standard. The results of all the analyses are given as means of three independent replicates \pm SE.

\section{Enzymatic activity assay}

Extraction of proteins and enzymatic activity assays have been described earlier (Lahuta 2006; Lahuta and Górecki 2011; Peterbauer et al. 2001). The activity of galactinol synthase (GolS), raffinose synthase (RS) and stachyose synthase (STS) was determined by the incubation of desalted extracts (from epicotyls and roots) with appropriate substrates in gel filtration buffer $(50 \mathrm{mM}$ HEPES$\mathrm{NaOH}, \mathrm{pH} 7.0,1 \mathrm{mM}$ DTT). The final reaction volume (30 $\mu \mathrm{L}$ ) for GolS activity assay contained $10 \mu \mathrm{L}$ of the desalted enzyme extract, $5 \mathrm{mM} \mathrm{MnCl}, 5 \mathrm{mM}$ UDP-galactose (Sigma) and $20 \mathrm{mM}$ myo-inositol. The activity of RS was 
assayed in a total volume of $30 \mu \mathrm{L}$ containing the enzyme extract $(20 \mu \mathrm{L}), 10 \mathrm{mM}$ galactinol and $40 \mathrm{mM}$ sucrose. The activity of STS was assayed in a total volume of $30 \mu \mathrm{L}$ containing the enzyme extract $(20 \mu \mathrm{L}), 10 \mathrm{mM}$ galactinol and $20 \mathrm{mM}$ raffinose. After 60,120 or $180 \mathrm{~min}$ of incubation (for GolS, STS and RS activity, respectively) at $30{ }^{\circ} \mathrm{C}$, the reaction was discontinued by adding $70 \mu \mathrm{L}$ of ethanol:water mixture $(8: 2, \mathrm{v} / \mathrm{v})$ and $10 \mu \mathrm{L}$ of internal standard (xylitol dissolved in water, at $10 \mathrm{mg} \mathrm{mL}^{-1}$ concentration), and boiling for $5 \mathrm{~min}$. After centrifugation (through $10000 \mathrm{MW}$ cutoff filters), the products of reactions (galactinol, raffinose and stachyose, respectively, for GolS, RS and STS) were dried, derivatized and analyzed by gas chromatography. The soluble protein content was determined using the Bradford's dye-binding procedure (Bio-Rad protein assay; Bio-Rad, Vienna) with bovine serum albumin (Sigma) as a standard. All reactions were performed on one sample from each of three replications of epicotyl or root tissues.

\section{Cloning of $5^{\prime}$ flanking regions for $P s G o l S$ and $P S R S$ genes}

The DNA fragments located upstream of the known cDNA sequences for PsGolS (AJ243815 and PsRS (AJ426475) were obtained by genome walking. Genomic DNA extracted from seedling leaves of $P$. sativum cv. Hubal using the cetyl trimethyl ammonium bromide (CTAB) technique (Rogers and Bendich 1994) was digested with restriction enzymes and ligated to Genome Walker Adaptor (Genome Walker Universal Kit, Clontech). To clone nucleotide sequences of promoters, one gene-specific primer (GSP) and adaptor primer (AP) were used each time. The GSPs for PsGols (5'AACGTTACGTATGCACGTT TCAGTTTC $3^{\prime}$ or $5^{\prime}$ GTAACTGGTTTCGTAGAGGTCTG AAC $\left.3^{\prime}\right), P s R S$ ( $5^{\prime}$ GATTGATGAGACTCGGATAGCTTA GTA $3^{\prime}$ or $5^{\prime}$ GTAGCTTTAAGTAACCGGTAGGAATG T3') and APs (5'GTAATACGACTCACTATAGGGC3' or 5'ACTATAGGGCACGCGTGGT3') were used in nested PCR. Two nested PCR procedures were performed to clone the nucleotide sequence of the PsGolS promoter. The primary DNA fragment (415 nucleotides), located upstream of the GolS transcription site, was extended by the second nested PCR using 5'ACACGTGTCAGTGTGAAATGAT CCAAT3' and 5'TCGGCTGGGAGTATCTACGTTTAGT $\mathrm{CA} 3^{\prime}$ reverse primers.

Amplified products were cloned to pGEMT (Promega) and sequenced. The resulting sequences were aligned by the Geneious software (Biomatters Inc, USA). Prediction of cis-acting elements was performed using the PLACE software (Higo et al. 1999; Prestridge 1991).

\section{Gene expression analysis}

Total RNA was extracted from three biological replicates, each consisting of epicotyls $(\mathrm{E})$ or roots $(\mathrm{R})$ pooled from ten seedlings from control $(\mathrm{C})$, treated with osmotic stress $(0,24$ and $48 \mathrm{~h})$ and rehydrated (Rec) samples. Epicotyls and roots stored in an ultra-freezer were ground in liquid nitrogen and extracted with modified methods described by Wang et al. (2012b). At the same time, RNA extraction buffer (100 mM Tris-HCl, pH 9.0, $2 \% \quad \beta$-mercaptoethanol, $1 \% \mathrm{SDS}$ ) and Tri-Reagent were added to the samples homogenized in liquid nitrogen. The isolated RNA $(5 \mu \mathrm{g})$ was treated with DNase (DNA-free, Promega), and cDNA synthesis was performed with Superscript II Reverse Transcriptase (Invitrogen) at $42{ }^{\circ} \mathrm{C}$ for $1 \mathrm{~h}$ using an oligo dT primer, according to the manufacturer's protocol. The oligonucleotides for PsGols mRNA (AJ243815) were forward 5'CACGAAACTGAAACGTGCAT3'/reverse 5' TCAGTTAAGCTGCCGAAGGT3'; for PsRS mRNA (AJ426475): forward 5'GGAACAAACGGACACGAAC T3'/reverse 5'AACTGGTCCACCAGAGATGG3'; PsSTS mRNA (AJ311087): forward 5'GTGTCGAACCGAGGT TTGTT3'/reverse 5'-TTCCCATTGGATCACCATTT3'; and for the $E F 1 \propto(\mathrm{X} 96555)$ an internal standard, forward 5'TTCCCTTCGTTCCCATCTCTG3'/reverse 5'TACAAG CATACCGGGCTTCA3' (Okorska et al. 2014). The semiquantitative PCR was performed on $2 \mu \mathrm{L}$ cDNA (equivalent to approximately $0.5 \mu \mathrm{g}$ starting RNA), $1 \mu \mathrm{M}$ each primers, $0.2 \mathrm{mM}$ of each dNTPs, $2.0 \mathrm{mM} \mathrm{MgCl}_{2}$, GoTaq buffer and $0.75 \mathrm{U}$ GoTaq polymerase (Promega) in $30 \mu \mathrm{L}$ total volume. The following conditions were used for PCR amplification of PsGolS (962 bp), PsRS (1287 bp) and PsSTS (930 bp): initial denaturation at $94{ }^{\circ} \mathrm{C}$ (4 min); touchdown cycles $\left[94{ }^{\circ} \mathrm{C}(30 \mathrm{~s}), 68-61{ }^{\circ} \mathrm{C}(30 \mathrm{~s}), 72{ }^{\circ} \mathrm{C}\right.$ (60 s)] (one cycle for each temperature) and 30 (PsGolS and $P s R S)$ or 25 (PsSTS) cycles at $94{ }^{\circ} \mathrm{C}(30 \mathrm{~s}), 61^{\circ} \mathrm{C}$ (30 s) and $72{ }^{\circ} \mathrm{C}(60 \mathrm{~s})$ followed by extension at $72{ }^{\circ} \mathrm{C}$ (10 min). Amplification of EFl $\alpha$ mRNA (236 bp) was carried out with $2 \mu \mathrm{L}$ cDNA under the following conditions set for PCR: initial denaturation at $94{ }^{\circ} \mathrm{C}$ (4 min): touchdown cycles $\left[94^{\circ} \mathrm{C}(15 \mathrm{~s}), 68-61{ }^{\circ} \mathrm{C}(15 \mathrm{~s}), 72{ }^{\circ} \mathrm{C}(30 \mathrm{~s})\right]$ (one cycle for each temperature) and 20 cycles at $94{ }^{\circ} \mathrm{C}$ (15 s), $61{ }^{\circ} \mathrm{C}(15 \mathrm{~s})$ and $72{ }^{\circ} \mathrm{C}(30 \mathrm{~s})$ followed by extension at $72{ }^{\circ} \mathrm{C}(5 \mathrm{~min})$. The intensity of bands was evaluated in a gel image analysis system (Gene Tools, Syngene).

\section{Statistical analysis}

The results were subjected to analysis of variance (ANOVA) and the Tukey's post-test (if overall $P<0.05$ ) for multiple comparisons. 


\section{Results}

\section{Changes in soluble carbohydrates during seed germination and seedling growth}

In dry pea seeds, RFOs were the main soluble carbohydrates in both the embryonic axis $\left(152 \mathrm{mg} \mathrm{g}^{-1} \mathrm{DW}\right)$ and cotyledons $\left(47 \mathrm{mg} \mathrm{g}^{-1} \mathrm{DW}\right)$. Although the concentration of RFOs in the axis was ca threefold higher than in cotyledons, stachyose was the main oligosaccharide (ca $50 \%$ of RFOs) in both parts of the embryo. During pea seed germination, RFOs were gradually degraded. The RFOs in the axis completely disappeared during the first $48 \mathrm{~h}$ of germination, but in cotyledons the degradation of RFOs was completed 6 days after the imbibition of seeds (data not shown). Based on the results of RFOs degradation, 5-day-old pea seedlings were chosen for the osmotic stress experiment. At this stage of development, RFOs are absent in epicotyls and roots, while other soluble sugars have reached stable concentrations in both seedling and cotyledon tissues.

\section{Osmotic stress}

After 5 days of germination and seedling growth, the epicotyl and root grew to the length of $29 \pm 2$ and $78 \pm 4 \mathrm{~mm}$, respectively. The fresh weight of epicotyls and roots decreased during $48 \mathrm{~h}$ of osmotic stress, due to water loss (Table 1). Epicotyls lost turgor (wilted) after the first few hours of stress (data not shown). However, after replacement of the PEG8000 solution with water (for $24 \mathrm{~h}$ ), seedlings were able to restore their turgor and epicotyls continued to grow (Table 1).

Under osmotic stress conditions, the concentration of total soluble carbohydrates (TSC: sucrose, glucose, fructose, myo-inositol, sorbitol, maltose, galactinol, raffinose plus stachyose) increased significantly $(P<0.05)$ in roots, but remained unchanged in epicotyl tissues (Table 2). Verbascose was absent in both epicotyl and root tissues.
The replacement of the PEG solution with water (recovery) caused a significant $(P<0.05)$ decrease in the concentration of TSC in both root and epicotyl (Table 2). In 5-dayold seedlings, the main sugars were fructose, glucose and sucrose (Fig. 1). Concentrations of other soluble carbohydrates were several-fold lower (myo-inositol was 3.6 and $4.2 \mathrm{mg} \mathrm{g}^{-1} \mathrm{DW}$ in the epicotyl and root, respectively, and sorbitol and maltose were at $<1 \mathrm{mg} \mathrm{g}^{-1} \mathrm{DW}$, data not shown). Changes in the concentration of sorbitol and maltose during osmotic stress were statistically not significant (data not shown). Concentrations of fructose (Fig. 1a, b) and glucose (Fig. 1c, d) significantly decreased during $48 \mathrm{~h}$ of seedling incubation in both water and PEG solution. The concentration of sucrose did not change significantly $(P>0.05)$ in control seedlings, but significantly increased (ca 3.5-fold) in seedlings incubated in the PEG solution (Fig. 1e, f). The concentration of sucrose in roots was about twice as high as in epicotyls (Fig. 1e, f). During $24 \mathrm{~h}$ of recovery, the concentration of sucrose decreased by ca $30 \%$, but remained twofold higher than in control seedlings. The concentration of sucrose in cotyledons increased ca twofold under osmotic stress (from 51.2 to $106.6 \mathrm{mg} \mathrm{g}^{-1} \mathrm{DW}$ ) and remained at a similar concentration during recovery (Supplementary Table A1).

\section{Accumulation of RFOs}

Galactinol, raffinose and stachyose were not detected in seedlings incubated for $72 \mathrm{~h}$ in water (control conditions). The accumulation of galactinol and RFOs (raffinose and stachyose; verbascose was not detected) was induced during the first $24 \mathrm{~h}$ of seedling incubation in a PEG solution (Figs. 2, 3). Prolonged stress increased the concentration of stachyose in the epicotyl and root (Figs. 3e, 4e). Between the 24th and 48th hour of stress, the concentration of galactinol decreased (Figs. 2a, 3a), but raffinose remained unchanged (Figs. 2c, 3c). After $48 \mathrm{~h}$ of osmotic stress, the total concentration of galactinol, raffinose and stachyose was 0.87 and $4.32 \mathrm{mg} \mathrm{g}^{-1}$ DW in epicotyl and root,
Table 1 Changes in fresh weight (FW), dry weight (DW) and water concentration (WC, as $\%$ of fresh weight) in the epicotyls and roots of 5-day-old pea seedlings before stress (initial), during $48 \mathrm{~h}$ of osmotic stress (PEG 8000, $-1.5 \mathrm{MPa}$ ) and after $24 \mathrm{~h}$ of recovery

\begin{tabular}{|c|c|c|c|c|c|c|}
\hline \multirow[t]{2}{*}{ Treatment } & \multicolumn{2}{|c|}{ FW (mg part $\left.{ }^{-1}\right)$} & \multicolumn{2}{|c|}{ DW (mg part $\left.{ }^{-1}\right)$} & \multicolumn{2}{|c|}{ WC (\%FW) } \\
\hline & Epicotyl & Root & Epicotyl & Root & Epicotyl & Root \\
\hline Initial & $125.7^{\mathrm{c}}$ & $118.0^{\mathrm{b}}$ & $9.9^{c}$ & $8.5^{\mathrm{c}}$ & $92.1^{\mathrm{a}}$ & $92.8^{\mathrm{a}}$ \\
\hline$-1.5 \mathrm{MPa}, 24 \mathrm{~h}$ & $91.4^{\mathrm{d}}$ & $64.8^{\mathrm{c}}$ & $12.7^{\mathrm{b}}$ & $9.4^{\mathrm{c}}$ & $86.0^{\mathrm{c}}$ & $85.4^{\mathrm{c}}$ \\
\hline$-1.5 \mathrm{MPa}, 48 \mathrm{~h}$ & $87.9^{\mathrm{d}}$ & $66.3^{\mathrm{c}}$ & $13.9^{\mathrm{b}}$ & $10.9^{\mathrm{b}}$ & $84.1^{\mathrm{d}}$ & $83.6^{\mathrm{d}}$ \\
\hline Recovery, 24 h & $147.6^{\mathrm{b}}$ & $109.8^{\mathrm{b}}$ & $13.8^{\mathrm{b}}$ & $9.1^{\mathrm{c}}$ & $90.6^{\mathrm{b}}$ & $91.7^{\mathrm{b}}$ \\
\hline Control $\left(\mathrm{H}_{2} \mathrm{O}\right)$ & $198.6^{\mathrm{a}}$ & $180.6^{\mathrm{a}}$ & $18.1^{\mathrm{a}}$ & $13.3^{\mathrm{a}}$ & $90.9^{\mathrm{b}}$ & $92.6^{\mathrm{a}}$ \\
\hline
\end{tabular}

As control, seedlings incubated for $72 \mathrm{~h}$ in water only were used. Values are means $(n=3)$. Values with different superscripts $(\mathrm{a}-\mathrm{d})$ are significantly different $(P<0.05)$ after a Tukey's correction for multiple comparisons for epicotyl and root separately (comparisons valid within columns only) 
Table 2 Changes in the concentration of total soluble carbohydrates in the epicotyl and root of 5-day-old pea seedlings before stress (initial), during $48 \mathrm{~h}$ of osmotic stress (PEG8000, -1.5 MPa) and after $24 \mathrm{~h}$ of recovery

\begin{tabular}{lcc}
\hline Treatment & Epicotyl $\left(\mathrm{mg} \mathrm{g}^{-1} \mathrm{DW}\right)$ & Root $\left(\mathrm{mg} \mathrm{g}^{-1} \mathrm{DW}\right)$ \\
\hline Initial & $158.28^{\mathrm{a}} \pm 4.28$ & $124.90^{\mathrm{c}} \pm 2.59$ \\
$-1.5 \mathrm{MPa}, 24 \mathrm{~h}$ & $168.60^{\mathrm{a}} \pm 2.86$ & $144.12^{\mathrm{b}} \pm 1.64$ \\
$-1.5 \mathrm{MPa}, 48 \mathrm{~h}$ & $167.44^{\mathrm{a}} \pm 2.20$ & $161.12^{\mathrm{a}} \pm 4.42$ \\
Recovery, 24 h & $131.01^{\mathrm{b}} \pm 0.96$ & $116.87^{\mathrm{c}} \pm 3.49$ \\
Control $\left(\mathrm{H}_{2} \mathrm{O}\right)$ & $95.58^{\mathrm{c}} \pm 2.59$ & $96.32^{\mathrm{d}} \pm 2.82$
\end{tabular}

As control, seedlings incubated for $72 \mathrm{~h}$ in water only were used. Values are means $(n=4) \pm$ SE. Values with different superscripts (a-d) are significantly different $(P<0.05)$ after a Tukey's correction for multiple comparisons for the epicotyl and root separately (comparisons valid within columns only)

respectively. The concentration of raffinose was tenfold higher in the root than in the epicotyl (Figs. 3c, 2c), unlike stachyose whose concentration was fivefold higher in the epicotyl than in the root (Figs. 2e, 3e). Galactosides (galactinol and RFOs) constituted only 0.5 and $2.7 \%$ of the TSC fraction in the epicotyl and root, respectively. The replacement of the PEG solution with water caused a decrease in the concentration of galactinol below the limits of detection and a decrease in the concentration of raffinose (Figs. 2a, c, 3a, c). However, the accumulation of stachyose in epicotyls continued (Fig. 2e).

Raffinose and stachyose, occurring in cotyledons before osmotic stress at low concentrations $\left(0.18\right.$ and $1.06 \mathrm{mg} \mathrm{g}^{-1}$ DW, respectively), were degraded during stress and recovery (Table A1).

\section{Enzyme activity}

The accumulation of galactinol and raffinose during the first $24 \mathrm{~h}$ of osmotic stress coincided with an induction of the activity of appropriate enzymes: galactinol synthase (GolS) and raffinose synthase (RS) (Figs. 2b, d, 3b, d). As the stress conditions persisted, the activity of GolS and RS decreased. During recovery, GolS activity declined to the activity before osmotic stress (Figs. $2 \mathrm{~b}, 3 \mathrm{~b}$ ). The activity of RS also decreased in roots although to a lesser extent (Fig. 3d), but remained unchanged in the epicotyl (Fig. 2d). Changes in the activity of stachyose synthase (STS) were different from changes in the activities of GolS and RS. The STS activity significantly decreased during the first $24 \mathrm{~h}$ of osmotic stress in the epicotyl (Fig. 2f), but increased in roots up to $48 \mathrm{~h}$ of stress (Fig. 3f). During recovery, the activity of STS decreased in both the epicotyl and root tissues. The activity of GolS was much higher than RS and STS, regardless of the type of tissue and seedling
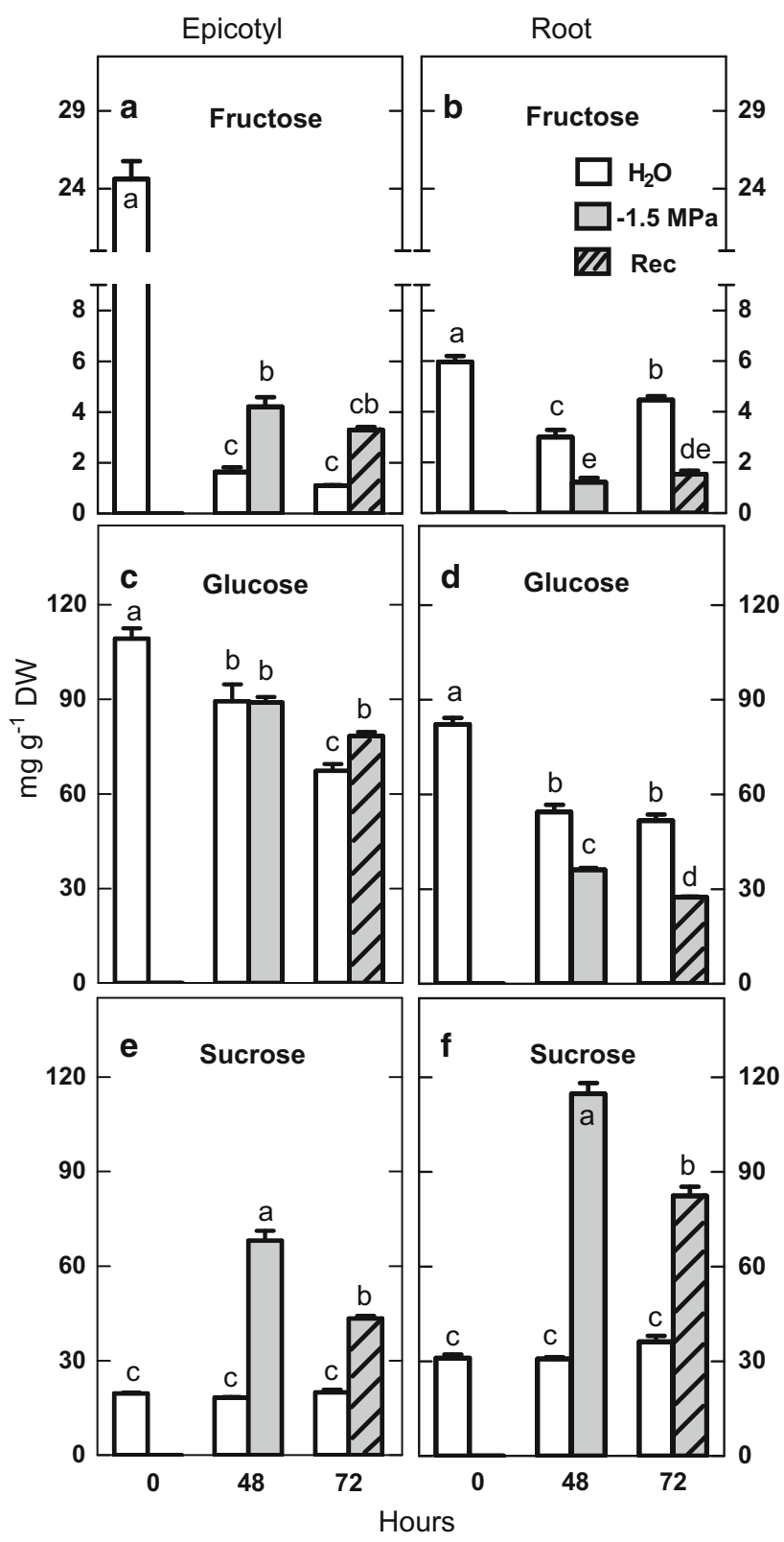

Fig. 1 The concentrations of fructose $(\mathbf{a}, \mathbf{b})$, glucose $(\mathbf{c}, \mathbf{d})$ and sucrose $(\mathbf{e}, \mathbf{f})$ in the epicotyls $(\mathbf{a}, \mathbf{c}, \mathbf{e})$ and roots $(\mathbf{b}, \mathbf{d}, \mathbf{f})$ of 5-day-old pea seedlings before $(0 \mathrm{~h})$, after $48 \mathrm{~h}$ of osmotic stress $(-1.5 \mathrm{MPa})$ and after $24 \mathrm{~h}$ of replacement of PEG8000 solution with water (Recovery, Rec). Control seedlings $\left(\mathrm{H}_{2} \mathrm{O}\right)$ were incubated in water only. Average values are given. Error bars represent the standard error $(n=3)$ and different letters $(a-e)$ above the bar represent the statistically significant difference at $P<0.05$ (Tukey's correction for multiple comparisons)

treatment (Figs. 2b, d, f, 3b, d, f). Moreover, the maximum activities of GolS and RS in roots (reached after $24 \mathrm{~h}$ of osmotic stress) were ca 10 - and 2.5 -fold higher than in epicotyls. 


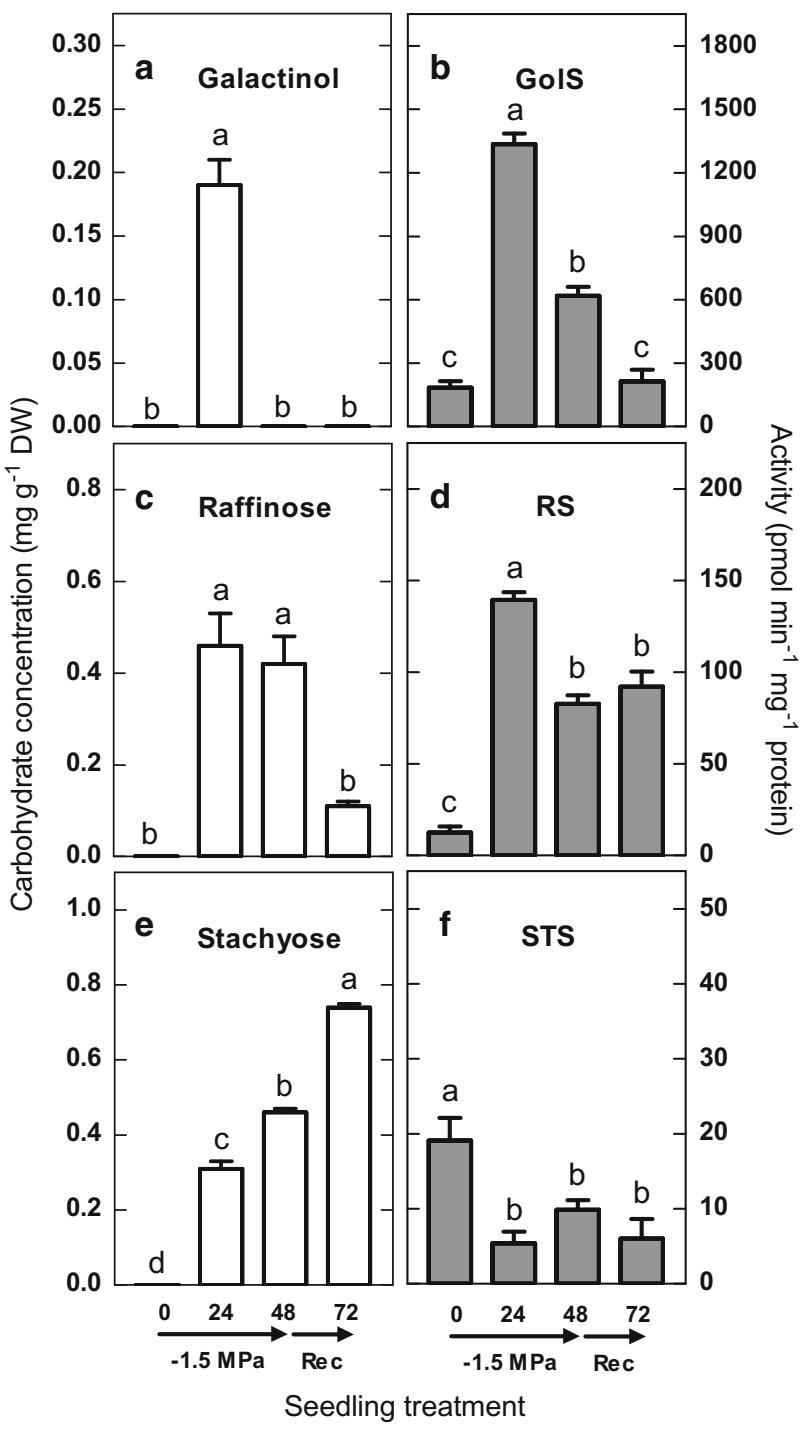

Fig. 2 The effect of osmotic stress (-1.5 MPa) on the accumulation of galactinol (A), raffinose (c), stachyose (e) and activity of GolS (b), RS (d) and STS (f) in epicotyls of 5-day-old pea seedlings at 0, 24 and $48 \mathrm{~h}$ and after $24 \mathrm{~h}$ of replacement of PEG8000 solution with water (Rec). Galactinol, raffinose and stachyose were not detectable in seedlings before stress. The average values are given. Error bars represent the standard error $(n=3)$ and different letters $(a-d)$ above the bar represent the statistically significant difference at $P<0.05$ (Tukey's correction for multiple comparisons)

\section{Expression of PsGolS, PsRS and PsSTS genes}

The transcripts of PsGolS and PsRS genes were present in both the epicotyl and root tissues before osmotic stress (Fig. 4a). PsGolS mRNA increased until $24 \mathrm{~h}$ of osmotic stress in both the epicotyl and root tissues (2.6- and 3.7fold, respectively, Fig. $4 \mathrm{a}, \mathrm{b}$ ). During the next $24 \mathrm{~h}$ of stress, the expression of PsGolS slightly decreased. After $24 \mathrm{~h}$ of recovery, the expression of PsGolS dramatically decreased to ca $50 \%$ lower than before stress. Osmotic stress also induced the expression of PsRS, but in the

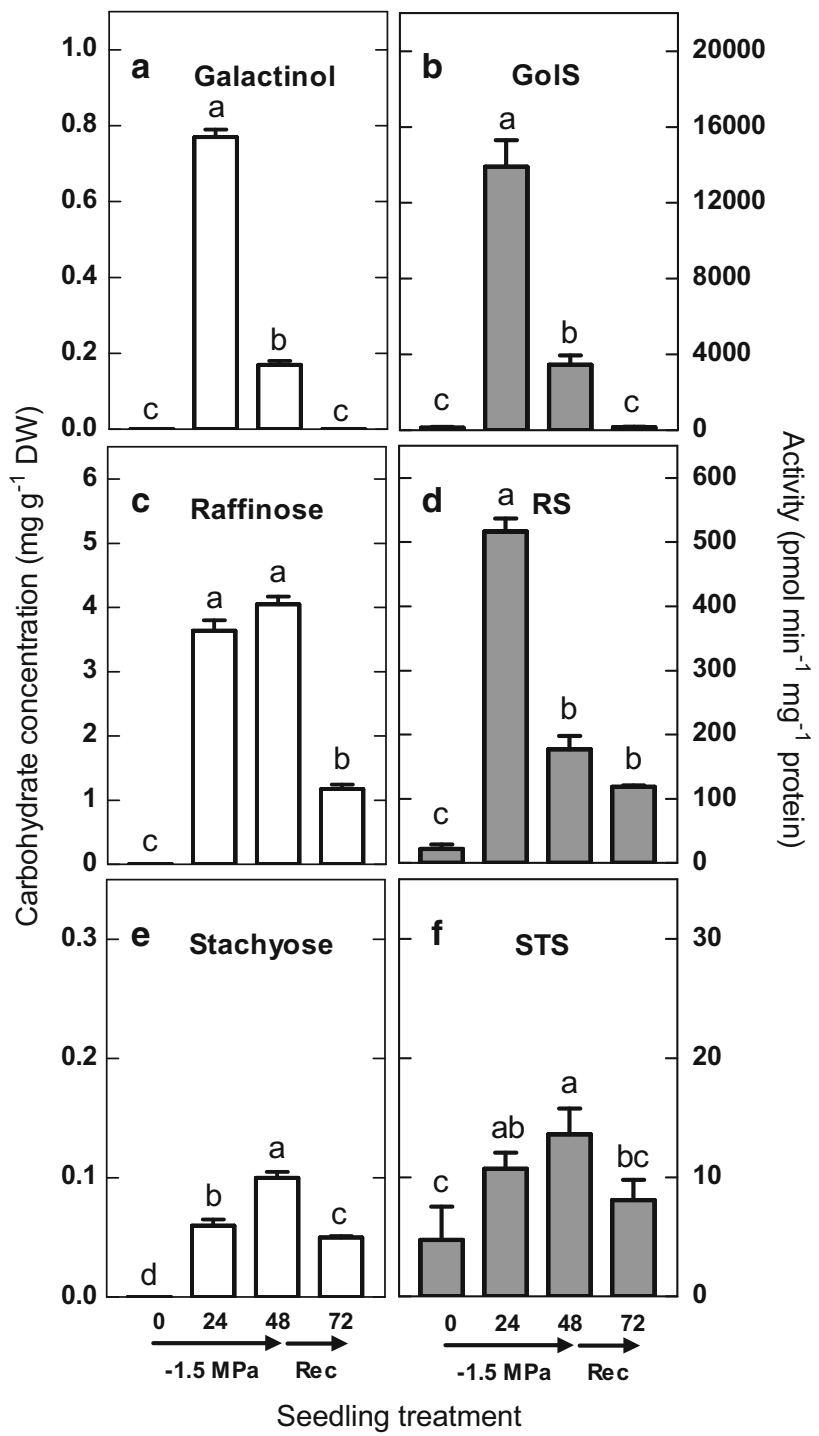

Fig. 3 The effect of osmotic stress (-1.5 MPa) on the accumulation of galactinol (a), raffinose (c), stachyose (e) and activity of GolS (b), RS (d) and STS (f) in roots of 5-day-old pea seedlings at 0, 24 and $48 \mathrm{~h}$ and after $24 \mathrm{~h}$ of replacement of PEG8000 solution with water $(\mathrm{Rec})$. Galactinol, raffinose and stachyose were not detectable in seedlings before stress. Average values are given. Error bars represent the standard error $(n=3)$ and different letters $(a-$ d) above the bar represent the statistically significant difference at $P<0.05$ (Tukey's correction for multiple comparisons)

epicotyl only (Fig. 4a). The expression of PsRS and PsSTS genes in epicotyls increased during the first $24 \mathrm{~h}$ of osmotic stress (1.3- and 3.1-fold, respectively). Then the level of PsRS and PsSTS gene expression decreased (Fig. 4a, b). During recovery, the expression of both genes decreased as well. In roots, the expression of $P S R S$ decreased under osmotic stress (Fig. 4a), while PsSTS did not change. After recovery, the expression of both genes in roots and epicotyls were much lower than before stress and comparable with the control (Fig. 4a). 
Fig. 4 The effect of osmotic stress $(-1.5 \mathrm{MPa})$ on the accumulation of PsGolS, PsRS and PSSTS transcript in the epicotyls (E) and roots (R) of 5-day-old pea seedlings at 0,24 and $48 \mathrm{~h}$ and after $24 \mathrm{~h}$ of recovery (Rec). Control, untreated seedlings that were grown in the water for 3 days are marked by $\mathrm{C}$.

a Representative gel of RT PCR for PsGolS, PsRS and PsSTS.

The rRNA represents the quality of extracted RNA $(2 \mu \mathrm{g})$. b mRNA fold change of PsGolS, PsRS and PsSTS relative to $P S E F$ used as the control gene. Average values are given. Error bars represent the standard error $(P<0.05$, Mann-Whitney $U$ test, $n=3$ )
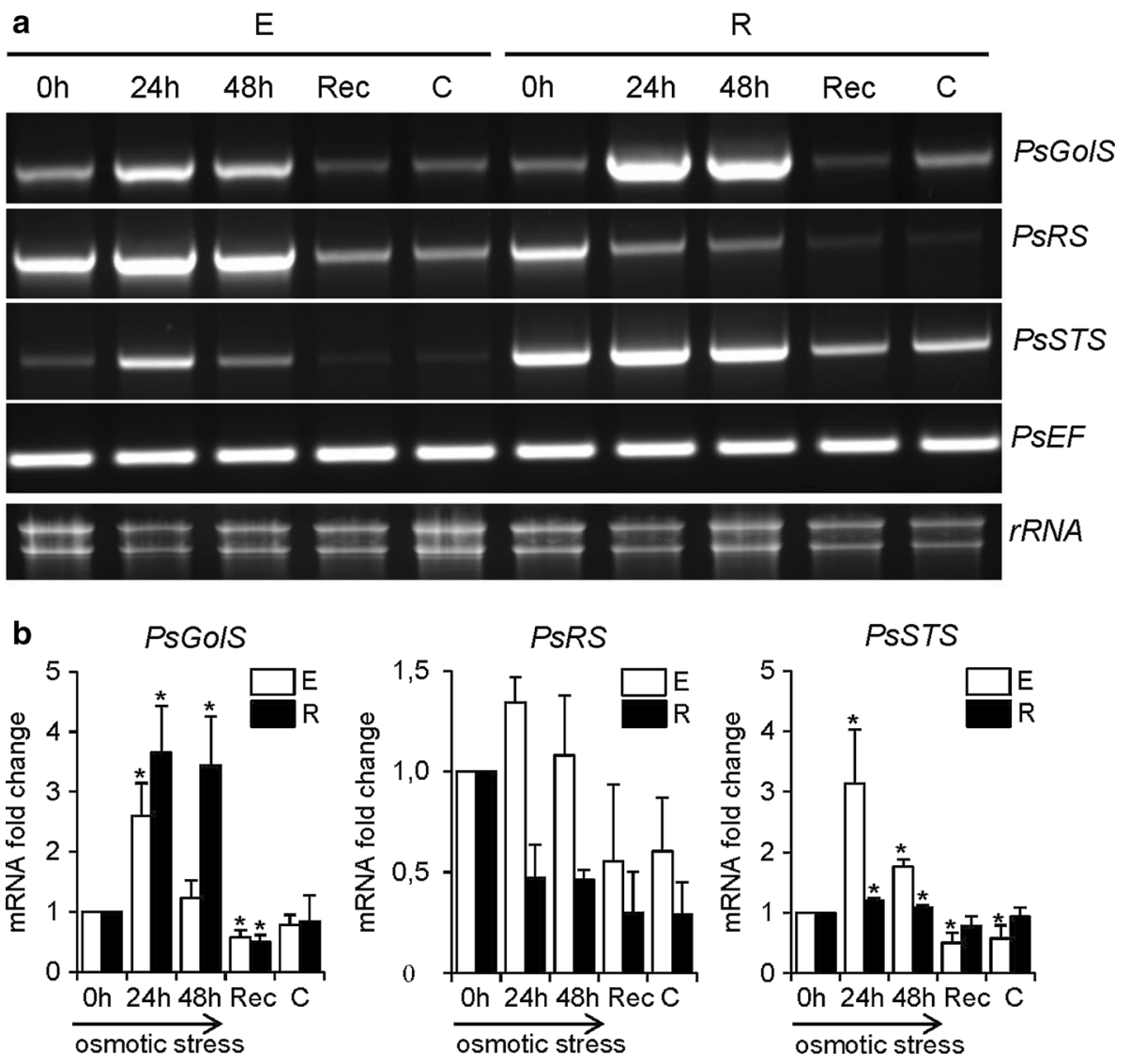

survive osmotic stress for $48 \mathrm{~h}$ (Table 1). Thus, changes in the concentration of soluble carbohydrates seem to be part of the plant's metabolic adjustment to osmotic stress conditions. With regard to the highest concentrations of glucose, sucrose and fructose among soluble carbohydrates in pea seedlings, it can be expected that changes in their concentrations adjust cell's osmotic potential to water stress. Indeed, osmotic stress induced the accumulation of sucrose in both epicotyls and roots of pea (Fig. 1e, f), like in seedlings of wheat (Bogdan and Zagdanska 2006), winter vetch (Lahuta and Górecki 2011) or desiccated seedlings of pea (Koster and Leopold 1988; Lahuta et al. 2014), yellow lupine (Górecki et al. 1997) and common buckwheat (Brenac et al. 2013). The accumulation of sucrose coincided with an appropriate decrease in the concentration of monosaccharides in the epicotyl (Fig. 1a, c) and root (Fig. 1b, d). However, the decrease in glucose and fructose (by 46 and $5 \mathrm{mg} \mathrm{g}^{-1} \mathrm{DW}$ ) in roots was insufficiently high to explain the increase in sucrose (by $84 \mathrm{mg} \mathrm{g}^{-1}$ DW, Fig. 1f). It means that sucrose accumulated in seedlings (especially in root) under osmotic stress can be derived from an additional influx of sucrose from cotyledons. Such transport of sucrose from storage tissues was suggested earlier in dehydrated coleoptiles of wheat (Farrant et al. 2004). With regard to the very low 
Table 3 Potential cis-acting elements present in promoter sequences of PsGolS and PsRS gene

\begin{tabular}{|c|c|c|c|c|}
\hline \multirow[t]{2}{*}{ Elements (sequence) } & \multicolumn{2}{|l|}{ Gene } & \multirow[t]{2}{*}{ References } & \multirow[t]{2}{*}{ Function } \\
\hline & PsGols & PsRS & & \\
\hline \multirow{2}{*}{$\begin{array}{l}\text { ABRE-like binding motif } \\
\text { (ACGTG) }\end{array}$} & $(+)-84$ & $(+)-755$ & \multirow[t]{2}{*}{ Nakashima et al. (2006) } & \multirow{6}{*}{$\begin{array}{l}\text { Binding of bZIP associated } \\
\text { with ABA response }\end{array}$} \\
\hline & $(-)-85$ & $(-)-756$ & & \\
\hline \multirow[t]{2}{*}{ CACGTG-containing ABRE } & $(+)-85$ & $(+)-756$ & \multirow[t]{2}{*}{ Chandrasekharan et al. (2003) } & \\
\hline & $(-)-85$ & $(-)-756$ & & \\
\hline \multirow{6}{*}{$\begin{array}{l}\text { DPBFCOREDCDC3 } \\
\text { (ACACNNG) } \\
\text { MYCCONSENSUSAT } \\
\text { (CANNTG) }\end{array}$} & $(+)-86$ & $(+)-757$ & \multirow[t]{2}{*}{ Kim et al. (1997) } & \\
\hline & $(-)-175,(-)-85$ & & & \\
\hline & $(+)-423,(+)-85$ & $(+)-756,(+)-572$ & \multirow[t]{4}{*}{ Abe et al. (2003) } & \multirow{4}{*}{$\begin{array}{l}\text { MYC recognition site in the } \\
\text { promoters of the } \\
\text { dehydration-responsive } \\
\text { genes }\end{array}$} \\
\hline & \multirow{3}{*}{$(-)-423,(-)-85$} & $(+)-497,(+)-220$ & & \\
\hline & & $(-)-756,(-)-572$ & & \\
\hline & & $(-)-497,(-)-220$ & & \\
\hline MYB1AT (WAACCA) & $(+)-110$ & \multirow{3}{*}{$(-)-409,(-)-340$} & Abe et al. (2003) & \multirow{4}{*}{$\begin{array}{l}\text { MYB recognition site in the } \\
\text { promoters of the } \\
\text { dehydration-responsive } \\
\text { genes }\end{array}$} \\
\hline MYB2CNSENSUSAT & \multirow[t]{2}{*}{$(-)-423$} & & \multirow[t]{2}{*}{ Abe et al. (2003) } & \\
\hline (YAACKG) & & & & \\
\hline MYBCORE (CNGTTR) & $(+)-423,(+)-372$ & $(+)-409,(+)-340$ & Urao et al. (1993) & \\
\hline MYB1LEPR (GTTAGTT) & \multirow[t]{3}{*}{$(+)-370$} & & Chakravarthy et al. (2003) & \multirow{3}{*}{$\begin{array}{l}\text { Ethylene-responsive } \\
\text { element }\end{array}$} \\
\hline ERELEE4 & & $(+)-484,(+)-210$ & \multirow[t]{2}{*}{ Montgomery et al. (1993) } & \\
\hline AWTTCAAA & & $(+)-203,(-)-648$ & & \\
\hline GT1GMSCAM4 & $(+)-295$ & $(+)-583$ & \multirow[t]{2}{*}{ Park et al. (2004) } & \multirow{2}{*}{$\begin{array}{l}\text { Pathogen and salt-induced } \\
\text { response }\end{array}$} \\
\hline (GAAAAA) & $(-)-272$ & $(-)-291,(-)-85$ & & \\
\hline W-box & $(+)-204,(+)-88$ & $(+)-238,(+)-715$ & \multirow[t]{2}{*}{ Xie et al. (2005) } & \multirow[t]{2}{*}{ WRKY binding sequence } \\
\hline (TGAC) & $(-)-76,(-)-458$ & $(-)-699,(-)-747$ & & \\
\hline
\end{tabular}

Numbers indicate nucleotide upstream of the $5^{\prime}$ end of transcription start sites of the PsGolS and PsRS genes. Minus or plus in brackets indicates the strand of DNA

concentrations of monosaccharides in pea cotyledons before and during osmotic stress (Table A1), the additional sources of substrates for sucrose synthesis must be activated. It can be suggested that starch can play this function, similar to that in germinating cereals (Yu et al. 1996). Sucrose accumulated in pea tissues under osmotic stress was partially (by ca $30 \%$ ) utilized in both the epicotyl and root during $24 \mathrm{~h}$ of recovery, but sucrose remained constant in cotyledons. Unexpectedly, the degradation of sucrose in seedling tissues did not increase the concentration of monosaccharides. Thus, it can be concluded that the rate of degradation of sucrose and utilization of monosaccharides were regulated by the metabolic demand of tissues during the restoration of seedling growth.

\section{Accumulation of galactinol and RFOs}

The incubation of pea seedlings in PEG solution induced the accumulation of galactinol and RFOs (raffinose and stachyose) in both epicotyls and roots (Figs. 2, 3), but not in cotyledons (Table A1). Because cotyledons of 5-day-old pea seedlings were undergoing programmed cell death, the cotyledons were unable to respond to osmotic signals resulting in the accumulation of RFOs, as observed in epicotyls and roots. Galactinol and raffinose were degraded during seedlings' rehydration for 24 h (Figs. 2, 3), analogously to previous finding in seedlings of winter vetch (Lahuta and Górecki 2011). Similar changes in the concentration of raffinose under a desiccation/rehydration treatment were revealed in seedlings of wheat (Bogdan and Zagdańska 2006). In seedlings of transgenic rice over-expressing the transcription factor encoding the OsWRKY11 gene, raffinose was accumulated to a concentration as high as sucrose (up to $20 \mu \mathrm{g} \mathrm{g}^{-1}$ fresh weight), which was sufficient for the osmotic adjustment of cells (Wu et al. 2009). In pea seedlings, the concentration of raffinose in roots was higher $\left(4.2 \mathrm{mg} \mathrm{g}^{-1} \mathrm{DW}\right.$, Fig. 3b) than in seedlings of wild-type rice (ca $0.2 \mathrm{mg} \mathrm{g}^{-1} \mathrm{DW}$, Morsy et al. 2007), but much lower than in hypocotyls of buckwheat (ca $23 \mathrm{mg} \mathrm{g}^{-1} \mathrm{DW}$, Brenac et al. 2013). The accumulation of stachyose in response to water stress is less documented, although it was confirmed in seedlings of rice (Morsy et al. 2007) and buckwheat (Brenac et al. 2013).

Our study reveals that pea seedlings under osmotic stress are able to accumulate stachyose, in addition to galactinol and raffinose. Epicotyls accumulated more 
stachyose than raffinose and galactinol (Fig. 2), opposite to roots, accumulating mainly raffinose (Fig. 3). Similarly to raffinose, stachyose was degraded during recovery in roots (Fig. 3e), confirming the transitory accumulation of RFOs under osmotic stress. The increase in stachyose concentration in epicotyls (by $0.2 \mathrm{mg} \mathrm{g}^{-1} \mathrm{DW}$ ) during recovery coincided with an appropriate decrease in raffinose concentration (by $0.3 \mathrm{mg} \mathrm{g}^{-1} \mathrm{DW}$ ), suggesting continuous synthesis of stachyose using previously accumulated raffinose (Fig. 2c, e).

With regard to the higher concentration of RFOs in roots than in epicotyls (4.2 and 0.8 and $\mathrm{mg} \mathrm{g}^{-1} \mathrm{DW}$, respectively) after $48 \mathrm{~h}$ of osmotic stress, it can be suggested that accumulation of RFOs is associated with the location of stress perception. However, the osmoprotective role of galactinol and RFOs, occurring at much lower concentrations than other sugars (Fig. 1), could be meaningful in specific cell compartments. Data are not available on the intracellular location of RFOs in pea vegetative tissues. On the other hand, the fast activation of RFOs biosynthesis in early response (1-4 h) of pea seedlings to dehydration (Lahuta et al. 2014), when no significant changes in the water concentration in tissues occurred, suggests that RFOs may play a role as signal molecules. The signaling effect of galactinol and RFOs (Keunen et al. 2013) seems to be related to the formation of reactive oxygen species (ROS) in tissues exposed to a broad range of abiotic stresses (Rosenwasser et al. 2013). The production of extracellular ROS during pea seed germination and seedling development (Kranner et al. 2010) is accelerated during seedling desiccation (Roach and Kranner 2011. It cannot be excluded that galactinol, raffinose and stachyose act as antioxidants (Nishizawa et al. 2008; Nishizawa-Yokoi et al. 2008). Recent studies suggest a link between sucrose and RFOs and oxidative defense via involvement of sugars in stabilizing membrane-associated peroxidases and NADPHoxidases (Van den Ende and Valluru, 2009).

\section{Expression of PsGolS, PSRS and PsSTS genes and activity of enzymes}

In unstressed pea seedlings, detectable activity of GolS, RS and STS (Figs. 2, 3) as well as PsGolS, PsRS and PsSTS transcripts (Fig. 4) was found in both the epicotyl and root. The dramatic increase in the activity of GolS and accumulation of galactinol during the first $24 \mathrm{~h}$ of osmotic stress coincided with the induction of expression of the PsGolS gene. The ca 14-fold higher GolS activity in roots than in epicotyls (Figs. 3b, 2b) was presumably an effect of higher expression of the PsGols gene (Fig. 4) and biosynthesis of the enzyme. A similar induction of PsGolS expression was detected previously in pea seedlings fast dehydrated for $24 \mathrm{~h}$ (Lahuta et al.
2014). The increasing activity of GolS leads to accumulation of galactinol and, later on, to raffinose, due to the increasing activity of RS (Figs. 2d, 3d). In contrast to $P s G o l S$, the expression of PsRS was induced by osmotic stress in epicotyls, but repressed in roots (Fig. 4). Despite these differences, the activity of RS increased in both epicotyl and root of pea seedling during the first $24 \mathrm{~h}$ of osmotic stress, but thereafter decreased (Figs. 2b, 3d). It can be suggested that osmotic stress induced in roots the expression of another PsRS gene, not investigated in our study. On the other hand, the regulation of RS via posttranslational modification may have taken place. Besides the increasing expression of PsRS (Fig. 4b), the activity of RS in the epicotyl (Fig. 2d) was much lower than that in roots (Fig. 3d). The decrease in the raffinose content in the epicotyl during recovery could have resulted from its use for the synthesis of stachyose (Fig. 2). Although the activity of STS was lower than that of other enzymes of the RFOs pathway (Fig. 2f), it was sufficient to produce elevated amounts of stachyose during $24 \mathrm{~h}$ of recovery (Fig. 2e). The PsSTS expression was induced by osmotic stress in epicotyls, but unaffected in roots. The expression of all investigated genes, activities of corresponding enzymes and concentrations of galactinol and RFOs were dramatically decreased after recovery (except stachyose accumulated in the epicotyl; Fig. 2e).

The activation of RFOs biosynthetic pathway in early response to osmotic stress and deactivation after recovery confirms the direct involvement of RFOs in seedling response to stress. However, the different expression patterns of PsGolS, PsRS and PSSTS and decrease in activity of GolS and RS during prolonged osmotic stress (between the 24th and 48th hours) suggest differences in the regulation of gene expression and possible instability of proteins under osmotic stress conditions. Moreover, PsGolS, $P s R S$ and PsSTS genes, identified in pea seedlings, can be only some members of GolS, RS and STS gene families that occur in pea tissues. Our previously published data show that there are more than one PsGolS and PsRS genes (Lahuta et al. 2014); however, only one of each of them have been cloned so far. In other plant species, abiotic stresses up-regulated the expression of different GolS and $R S$ genes (Taji et al. 2002; Wang et al. 2012a; Zhou et al. 2012, 2014), indicating the complexity of galactinol and RFOs regulation under stress conditions. The induction of the expression of GolS genes in response to water stress was demonstrated in vegetative tissues of different plant species. Drought and salinity stress induced the expression of GolS genes (AtGolS1, AtGolS2 and AtGolS3) in leaves of Arabidopsis (Taji et al. 2002), Salvia miltiorrhiza (Wang et al. 2012a) and Populus trichocarpa (Zhou et al. 2014). In Populus trichocarpa seedlings, water-deficit stress 
treatments continued to up-regulate the PtrGols gene expression after 2 days of treatment, in addition to an early induction within $24 \mathrm{~h}$ of treatment. Consistent with these expression patterns, the galactinol content in leaves increased after 4 days of drought stress (Zhou et al. 2014). In cucumber plants, the induction of $C s R S$ expression in leaves after $1 \mathrm{~h}$ of cold stress and the following increase in CsRS transcripts correlated with an increasing activity of RS and accumulation of raffinose under cold stress (Sun et al. 2013).

\section{Putative cis-elements in the promoter regions of the PsGolS and PsRS genes}

Knowledge concerning upstream regulators that activate the expression of genes encoding GolS and RS is limited. Most of the published data show that ABA mediates the activity of galactinol synthase on an mRNA or protein basis (ElSayed et al. 2014). The presence of putative cisregulatory elements of cloned nucleotide sequences located upstream of PsGolS and PsRS genes from pea (Table 3) suggest that both genes might be involved in a response induced by ABA. The presence of cis-regulatory elements recognized by the transcription factor mediating the $\mathrm{ABA}$ response were shown in some GolS genes in Arabidopsis (Taji et al. 2002) and Populus trichocarpa (Zhou et al. 2014). Additionally, ABA enhances the MoGolS1 mRNA transcription in Melissa officinalis plants (Kim et al. 2011) and PtrGolS genes that contain ABRE elements in the promoter region (Zhou et al. 2014). The transcription of PtrGolS4 mRNA that lacks ABRE elements in the $5^{\prime}$ flanking region was decreased by 24-h salt, osmotic, cold or ABA treatments in Populus trichocarpa (Zhou et al. 2014). Moreover, bioinformatics analysis reveals that WRKY transcription factors might act as upstream regulators of $P s G o l S$ as well as $P s R S$ genes. There are four putative W-box elements with a core sequence TGAC recognized by the WRKY transcription factor in PsGolS and PsRS genes (Table 3). Transgenic rice (Oryza sativa L.), overexpressing OsWRKY1ldriven by the HSP101 promoter, accumulates higher concentrations of raffinose after heat treatments compared with nontransgenic plants. Parallel to the increased concentration of raffinose, the upregulation of genes encoding galactinol synthase and raffinose synthase were shown. Additionally, a $5^{\prime}$ flanking sequence, which up-regulated the raffinose synthase gene, contains the putative W-box sequence that might be involved in its activation by OsWRKYII (Wu et al. 2009). A WRKY transcription factor participates in the dehydration tolerance of Boea hygrometrica by binding to the W-box elements of the galactinol synthase (BhGolSl) promoter, which leads to the accumulation of RFOs (Wang et al. 2009).

\section{Conclusion}

In summary, our data revealed that besides accumulation of sucrose in response to osmotic stress common for all tissues of pea seedlings, tissues of epicotyls and roots, but not cotyledons, accumulate RFOs (raffinose and stachyose). The accumulation of galactinol and RFOs coincides with changes in the expression of PsGols, PsRS and PsSTS genes and increasing activity of appropriate enzymes. The amount of synthesized galactosides presumably depends on stress intensity and duration and seems to be determined by the expression of $P s G o l S$ gene, whose promoter region was identified to contain some stress-related regulating elements. Seedlings of pea may be an excellent model system to study the molecular background of mechanisms regulating biosynthesis of RFOs under osmotic stress.

Author contribution statement Conceived and designed the experiments: LBL. Performed the experiments, collected and analyzed the data: WEP, JS and LBL. Wrote the manuscript: LBL and WEP. Helped draft the manuscript: RJG and RLO. All authors read and approved the final manuscript.

Acknowledgments This work was partially funded by grant No. NN310776440 provided by the National Centre of Science and by Ministry of Science and Higher Education of Poland.

Open Access This article is distributed under the terms of the Creative Commons Attribution 4.0 International License (http://crea tivecommons.org/licenses/by/4.0/), which permits unrestricted use, distribution, and reproduction in any medium, provided you give appropriate credit to the original author(s) and the source, provide a link to the Creative Commons license, and indicate if changes were made.

\section{References}

Abe H, Urao T, Ito T, Seki M, Shinozaki K, Yamaguchi-Shinozaki K (2003) Arabidopsis AtMYC2 (bHLH) and AtMYB2 (MYB) function as transcriptional activators in abscisic acid signaling. Plant Cell 15:63-78

Bogdan J, Zagdańska B (2006) Changes in the pool of soluble sugars induced by dehydration at the heterotrophic phase of growth of wheat seedlings. Plant Physiol Biochem 44:787-794

Brenac P, Horbowicz M, Smith ME, Obendorf RL (2013) Raffinose and stachyose accumulate in hypocotyls during drying of common buckwheat seedlings. Crop Sci 53:1615-1625

Chakravarthy S, Tuori RP, DAscenzo MD, Fobert PR, Despres C, Martin GB (2003) The tomato transcription factor Pti4 regulates defence-related gene expression via GCC box and non-GCC box cis elements. Plant Cell 15:3033-3050

Chandrasekharan MB, Bishop KJ, Hall TC (2003) Module-specific regulation of the beta-phaseolin promoter during embryogenesis. Plant J 33:853-866

ElSayed AI, Rafudeen MS, Golldack D (2014) Physiological aspects of raffinose family oligosaccharides in plants: protection against abiotic stress. Plant Biol 16:1-8 
Farrant JM, Bailly C, Leymarie J, Hamman B, Côme D, Corbineau F (2004) Wheat seedlings as a model to understand desiccation tolerance and sensitivity. Physiol Plant 120:563-574

Górecki RJ, Piotrowicz-Cieślak AI, Lahuta LB, Obendorf RL (1997) Soluble carbohydrates in desiccation tolerance of yellow lupin seeds during maturation and germination. Seed Sci Res 7:107-115

Górecki RJ, Lahuta LB, Hedley C, Jones A (2000) Soluble sugars in maturing pea seeds of different lines in relation to desiccation tolerance. In: Black M, Bradford KJ, Vasquez-Ramos J (eds) Seed biology: advances and applications, proceedings of the sixth international workshop on seeds, Merida, Mexico, CAB International, Wallingford, UK, pp 67-74

Guy C, Kaplan F, Kopka J, Selbig J, Hincha DK (2008) Metabolomics of temperature stress. Physiol Plant 132:220-235

Higo K, Ugawa Y, Iwamoto M, Korenaga T (1999) Plant cis-acting regulatory DNA elements (PLACE) database. Nucleic Acids Res 27:297-300

Keunen E, Peshev D, Vangronsveld J, Van Den Ende W, Cuypers A (2013) Plant sugars are crucial players in the oxidative challenge during abiotic stress: extending the traditional concept. Plant Cell Environ 7:1242-1255

Kim SY, Chung HJ, Thomas TL (1997) Isolation of a novel class of bZIP transcription factors that interact with ABA-responsive and embryo-specification elements in the Dc3 promoter using a modified yeast one-hybrid system. Plant J 11:1237-1251

Kim JH, Hossain AM, Kim N, Lee DH, Lee H (2011) Identification of functional characterization of the galactinol synthase (MoGolS1) gene in Melissa officinalis plants. J Appl Biol Chem 54:244-251

Komatsu S, Hossain Z (2013) Organ-specific proteome analysis for identification of abiotic stress response mechanism in crop. Front Plant Sci 4:71. doi:10.3389/fpls.2013.00071

Koster KL, Leopold AC (1988) Sugars and desiccation tolerance in seeds. Plant Physiol 88:829-832

Kranner I, Roach T, Beckett RP, Whitaker C, Minibayeva FV (2010) Extracellular production of reactive oxygen species during seed germination and early seedling growth in Pisum sativum. J Plant Physiol 167:805-811

Lahuta LB (2006) Biosynthesis of raffinose family oligosaccharides and galactosyl pinitols in developing and maturing seeds of winter vetch (Vicia villosa Roth.). Acta Soc Bot Pol 75:219-227

Lahuta LB, Górecki RJ (2011) Raffinose in seedlings of winter vetch (Vicia villosa Roth) under osmotic stress and followed by recovery. Acta Physiol Plant 33:725-733

Lahuta LB, Górecki RJ, Gojło E, Horbowicz M (2005) Differences in accumulation of soluble $\alpha$-galactosides during seed maturation of several Vicia species. Acta Physiol Plant 27:163-171

Lahuta LB, Pluskota WE, Stelmaszewska J, Szablińska J (2014) Dehydration induces expression of GALACTINOL SYNTHASE and RAFFINOSE SYNTHASE in seedlings of pea (Pisum sativum L.). J Plant Physiol 171:1306-1314

Maia J, Dekkers BJW, Dolle MJ, Ligterink W, Hilhorst HWM (2014) Abscisic acid (ABA) sensitivity regulates desiccation tolerance in germinated Arabidopsis seeds. New Phytol 203:81-93

Michel BE (1983) Evaluation of the water potentials of solutions of polyethylene glycol 8000. Plant Physiol 72:66-70

Montgomery J, Goldman S, Deikman J, Margossian L, Fischer RL (1993) Identification of an ethylene-responsive region in the promoter of a fruit ripening gene. Proc Natl Acad Sci USA 90:5939-5943

Morsy MR, Jouve L, Hausman JF, Hoffmann L, Stewart JMD (2007) Alteration of oxidative and carbohydrate metabolism under abiotic stress in two rice (Oryza sativa L.) genotypes contrasting in chilling tolerance. J Plant Physiol 164:157-167

Nakashima K, Fujita Y, Katsura K, Maruyama K, Narusaka Y, Seki M, Shinozaki K, Yamaguchi-Shinozaki K (2006) Transcriptional regulation of $\mathrm{ABI} 3-$ and $\mathrm{ABA}-$ responsive genes including RD29B and RD29A in seeds, germinating embryos, and seedlings of Arabidopsis. Plant Mol Biol 60:51-68

Nishizawa A, Yabuta Y, Shigeoka S (2008) Galactinol and raffinose constitute a novel function to protect plants from oxidative damage. Plant Physiol 147:1251-1263

Nishizawa-Yokoi A, Yabuta Y, Shigeoka S (2008) The contribution of carbohydrates including raffinose family oligosaccharides and sugar alcohols to protection of plant cells from oxidative damage. Plant Sign Behav 3:1016-1018

Obendorf RL (1997) Oligosaccharides and galactosyl cyclitols in seed desiccation tolerance. Seed Sci Res 7:63-74

Obendorf RL, Górecki RJ (2012) Soluble carbohydrates in legume seeds. Seed Sci Res 22:219-242

Obendorf RL, Zimmerman AD, Zhang Q, Castillo A, Kosina SM, Bryant EG, Sensenig EM, Wu J, Schnebly SR (2009) Accumulation of soluble carbohydrates during seed development and maturation of low-raffinose, low-stachyose soybean. Crop Sci 49:329-341

Okorska SB, Michalczyk DJ, Okorski A, Piotrowicz-Cieślak A, Głowacka K, Pupel P, Jagielska T, Górecki RJ (2014) Variability of PSPAL1 (phenylalanine ammonia-lyase gene-1) proximal promoter sequence and expression in pea challenged with Mycosphaerella pinodes. Czech J Genet Plant Breed 50:163-170

Park HC, Kim ML, Kang YH, Jeon JM, Yoo JH, Kim MC, Park CY, Jeong JC, Moon BC, Lee JH, Yoon HW, Lee SH, Chung WS, Lim CO, Lee SY, Hong JC, Cho MJ (2004) Pathogen- and NaClinduced expression of the SCaM-4 promoter is mediated in part by a GT-1 box that interacts with a GT-1-like transcription factor. Plant Physiol 135:2150-2161

Pastorczyk M, Giełwanowska I, Lahuta LB (2014) Changes in soluble carbohydrates in polar Caryophyllaceae and Poaceae plants in response to chilling. Acta Physiol Plant 36:1771-1780

Peterbauer T, Richter A (2001) Biochemistry and physiology of raffinose family oligosaccharides and galactosyl cyclitols in seeds. Seed Sci Res 11:185-197

Peterbauer T, Lahuta LB, Blöchl A, Mucha J, Jones DA, Hedley CL, Górecki RJ, Richter A (2001) Analysis of the raffinose family oligosaccharide pathway in pea seeds with contrasting carbohydrate composition. Plant Physiol 127:1764-1772

Prestridge DS (1991) SIGNAL SCAN: a computer program that scans DNA sequences for eukaryotic transcriptional elements. CABIOS 7:203-206

Qin F, Shinozaki K, Yamaguchi-Shinozaki K (2011) Achievements and challenges in understanding plant abiotic stress responses and tolerance. Plant Cell Physiol 52:1569-1582

Roach T, Kranner I (2011) Extracellular superoxide production associated with secondary root growth following desiccation of Pisum sativum seedlings. J Plant Physiol 168:1870-1873

Rogers SO, Bendich AJ (1994) Extraction of total cellular DNA from plants, algae and fungi. In: Gelvin SB, Schilperoort RA (eds) Plant molecular biology manual, 2nd edn. Kluwer Academic Publishers, Dordrecht, pp 183-190

Rosenwasser S, Fluhr R, Joshi JR, Leviatan N, Sela N, Hetzroni A, Friedman H (2013) ROSMETER: a bioinformatic tool for the identification of transcriptomic imprints related to reactive oxygen species type and origin provides new insights into stress responses. Plant Physiol 163:1071-1083

Singh AK, Rana MK, Singh S, Kumar S, Kumar R, Singh R (2014) CAAT box-derived polymorphism (CBDP): a novel promotertargeted molecular marker for plants. J Plant Biochem Biotechnol 23:175-183

Sun WQ, Leopold AC (1997) Cytoplasmic vitrification and survival of anhydrobiotic organisms. Compar Biochem Physiol A 117A:327-333 
Sun Z, Qi X, Wang Z, Li P, Wu C, Zhang H, Zhao Y (2013) Overexpression of $T s G O L S 2$, a galactinol synthase, in Arabidopsis thaliana enhances tolerance to high salinity and osmotic stresses. Plant Physiol Biochem 69:82-89

Taji T, Ohsumi C, Iuchi S, Seki M, Kasuga M, Kobayashi M, Yamaguchi-Shinozaki K, Shinozaki K (2002) Important roles of drought- and cold-inducible genes for galactinol synthase in stress tolerance in Arabidopsis thaliana. Plant J 29:417-426

Teakle GR, Manfield IW, Graham JF, Gilmartin PM (2002) Arabidopsis thaliana GATA factors: organization, expression and DNA-binding characteristics. Plant Mol Biol 50:43-57

Urao T, Yamaguchi-Shinozaki K, Urao S, Shinozaki K (1993) An Arabidopsis myb homolog is induced by dehydration stress and its gene product binds to the conserved MYB recognition sequence. Plant Cell 5:1529-1539

Valluru R, Van den Ende W (2011) myo-Inositol and beyondemerging networks under stress. Plant Sci 181:387-400

Van den Ende W, Valluru R (2009) Sucrose, sucrosyl oligosaccharides, and oxidative stress: scavenging and salvaging? J Exp Bot 60:9-18

Wang Z, Zhu Y, Wang L, Liu X, Liu Y, Phillips J, Deng X (2009) A WRKY transcription factor participates in dehydration tolerance in Boea hygrometrica by binding to the W-box elements of galactinol synthase (BhGolS1) promoter. Planta 230:1155-1166

Wang D, Yao W, Song Y, Liu W, Wang Z (2012a) Molecular characterization and expression of three galactinol synthase genes that confer stress tolerance in Salvia miltiorrhiza. J Plant Physiol 169:1838-1848
Wang G, Wang G, Zhang X, Wang F, Song R (2012b) Isolation of high quality RNA from cereal seeds containing high levels of starch. Phytochem Anal 23:159-163

Wu X, Kishitani S, Ito Y, Toriyama K (2009) Accumulation of raffinose in rice seedlings overexpressing $O s W R K Y 11$ in relation to desiccation tolerance. Plant Biotech 26:431-434

Xie Z, Zhang ZL, Zou X, Huang J, Ruas P, Thompson D, Shen QJ (2005) Annotations and functional analyses of the rice WRKY gene superfamily reveal positive and negative regulators of abscisic acid signaling in aleurone cells. Plant Physiol 137:176-189

Yancey PH (2005) Organic osmolytes as compatible, metabolic and counteracting cryoprotectants in high osmolarity and other stresses. J Exp Biol 208:2819-2830

Yu SM, Lee YC, Chan MT, Hwa SF, Liu LF (1996) Sugars act as signal molecules and osmotica to regulate the expression of alpha-amylase genes and metabolic activities in germinating cereal grains. Plant Mol Biol 30:1277-1289

Zhou ML, Zhang Q, Zhou M, Sun ZM, Zhu XM, Shao JR, Tang YX, Wu YM (2012) Genome-wide identification of genes involved in raffinose metabolism in maize. Glycobiology 22:1775-1785

Zhou J, Yang Y, Yu J, Wang L, Yu X, Ohtani M, Kusano M, Saito K, Demura T, Zhuge Q (2014) Responses of Populus trichocarpa galactinol synthase genes to abiotic stresses. J Plant Res 127:347-358 